\title{
LEARNING RESPONSIBILITY - TEACHING SUSTAINABILITY: EXPERIENTIAL AND TRANSFORMATIVE LEARNING IN A BUSINESS SCHOOL
}

\author{
A FENNTARTHATÓSÁG OKTATÁSA, A FELELŐSSÉG TANULÁSA: \\ TAPASZTALATI ÉS TRANSZFORMTÍV TANULÁS EGY GAZDASÁGI \\ EGYETEMEN
}

The emerging concept of responsible research and innovation (RRI) in some ways always relates to sustainability. In the transition towards sustainability, the authors need to build responsibility for both society and the environment in higher education and management education. Non-formal approaches to learning provide an opportunity to transform a student's 'head, heart and hand', including at the social level as well. This paper showcases the role of experiential and transformative learning in higher education practice. Two of their courses are described and analysed, which are intended to familiarise students with the problem of sustainability within economic higher education. The authors share the theoretical and practical experiences of designing, teaching and assessing these courses. They aim to contribute to the discussion on how business education could be producing useful and credible knowledge that addresses problems important to nature and society.

Keywords: RRI, experiential learning, transformative learning, education for sustainability

A felelősségteljes kutatás és innováció (RRI) kialakulóban lévő koncepciója bizonyos szempontból mindig kapcsolódik a fenntarthatósághoz. A fenntarthatóság felé történő átmenet során fel kell építeni a társadalom és a környezet iránti felelősséget a felsőoktatásban és a menedzsmentoktatásban egyaránt. A nem formális tanulási megközelítések lehetőséget adnak arra, hogy ez az átalakulás a hallgatók "fejében, szívében és kezében", valamint társadalmi szinten is megtörténjen. Ezen írás célja a tapasztalati és a transzformatív tanulás szerepének bemutatása a felsőoktatási gyakorlatban. Két olyan egyetemi kurzust ismertetnek és elemeznek a szerzők, amelyek célja a fenntarthatóság problémájának megismertetése a gazdasági felsőoktatás hallgatóival. Megosztják a kurzusok tervezésének, oktatásának és értékelésének elméleti és gyakorlati tapasztalatait. Céljuk, hogy hozzájáruljanak ahhoz a folyamathoz, amelynek eredményeképpen az üzleti oktatás olyan hasznos és hiteles tudást hoz létre, amely a természet és a társadalom számára fontos problémákkal foglalkozik.

Kulcsszavak: RRI, tapasztalati tanulás, transzformatív tanulás, fenntarthatóság, felsőoktatás

\section{Funding/Finanszírozás:}

The present publication is the outcome of the project From Talent to Young Researcher project aimed at activities supporting the research career model in higher education, identifier EFOP-3.6.3-VEKOP-16-2017-00007 co-supported by the European Union, Hungary and the European Social Fund.

\section{Authors/Szerzők:}

Dr. Gabriella Kiss, associate professor, Corvinus University of Budapest, (gabriella.kiss@uni-corvinus.hu)

Tamás Veress, PhD student, Corvinus University of Budapest, (tamas.veress@netorient.hu)

Dr. Alexandra Köves, associate professor, Corvinus University of Budapest, (alexandra.koves@uni-corvinus.hu)

This article was received: 04. 09. 2019, revised: 20. 08. 2020, accepted: 07. 06. 2021.

$\mathrm{T}$ he scientific discourse and the political action that appears in the climate movements both draw our attention to the unsustainability of our current modus operandi. For quite some time economic higher education has been reluctant to face its responsibility, however, times are changing, and it is becoming ever more pressing to acknowledge liability. In 2016 the Corvinus University of Budapest (CUB) hosted the annual meeting of deans and leaders of the EFMD (European Foundation for Management Development) universities and business colleges. 
In plenary speeches and some sections, the participants spoke with surprising sincerity about how it might be time to conduct self-examination, and to accept that business schools have a serious responsibility in the series of ecological and social crises in the world. This newly-found awareness also takes economic higher education closer to the concept of responsible research and innovation (RRI).

RRI is a flexible umbrella term emerging in both the political arena and in scientific discourse (Bajmócy \& Pataki, 2019; Karner et al., 2016;). It proposes to steer research and innovation agendas toward ecologically and socially relevant problems, or "grand challenges" (Schomberg, 2013). Multiple authors - see for example Deblonde (2015), Owen et al. (2012), and Stilgoe et al. (2013) - suggest that RRI's concepts and definitions are linked one way or another with the concepts of sustainability, strong sustainability or sustainable development. Deblonde (2015) explicitly argues that for RRI to fulfil its potential, it needs an ecological dimension that takes the 'strong' version of sustainable development as a normative starting point. Accordingly, RRI can be an overarching program for science, innovation and education, taking clear responsibility regarding society and nature. To reposition our socio-economic systems on sustainable trajectories, there need to be numerous transformations in - among other areas - social values and behavioural patterns (Capra \& Luisi, 2014; Steffen et al., 2018).

Economic higher education has an important role to play in such transformations. We educate the next generations of economists, managers, decision-makers, consumers and citizens. We have the opportunity to make our students conscious of their responsibility to the environment and society and develop their critical reflection skills. But how should this responsibility be taught? Is it possible for students - the majority of whom are in their early $20 \mathrm{~s}-$ to learn sustainability? Can a teacher influence student values and induce change in their frames of reference?

Acknowledging and facing our responsibility as educators and researchers at CUB, we deliberately design courses to build sustainability issues into economic education. The aim of this paper is to introduce two courses - and their underlying theoretical concepts - as attempts to embed sustainability as a major decision-making factor when acting as citizens, consumers or managers. Our basic assumption is that, due to its complexity, sustainability education needs to exceed the merely intellectual dimension (e.g., knowledge about how economic production destroys ecosystems). It should also affect student attitudes, and later have a spill-over effect on society as a whole. Accordingly, when designing our two courses, we turned to non-formal educational approaches: experiential and transformative learning. In this paper, we introduce both the courses and the educational theories inspiring and instructing us. Students on both courses are dealing with ecological and social problems, practice active citizenship, discuss sustainability issues and take part in participatory group learning processes.

The paper first provides a short overview of international and local discourses in the field of sustainability ed- ucation concerning economic higher education. Second, we introduce the theoretical approaches of experiential and transformative learning and then describe the two courses in which we applied them. In the discussion, we reflect on our teaching practices, whether in our understanding the courses delivered the expected results, and if not, where and why those shortcomings occurred. We intend to contribute to the discussion on sustainability education (see for example Cranton, 2002; Moore, 2005; Foster \& Stagl, 2018) based on our own experiences.

\section{Sustainability in economic higher education}

Many people all over the world demand the self-examination of economists regarding their responsibility for the ecological and social demises that the economy is creating or reinforcing. Whether it is enlightened students or academics in the Rethinking Economics movement, Harvard professors establishing Economics for Inclusive Prosperity or keynote speakers at the EFMD Deans' Conference in Budapest, they all insist on a reappraisal of mainstream paradigms. These initiatives are not just the demands of some strange, "tree-hugging", heterodox economists. Similarly to the blossoming climate movements, many of these changes are being initiated by the students themselves, as in the Rethinking Economics group who demand pluralism in economics teaching. The ingenuity and motivation of these actors are not relevant in this article, but their call to reassess the way we think and teach economics and management is.

In January 2018, the Rethinking Economics movement together with the New Weather Institute issued the 33 Theses of Economics Reformation and pinned the list to the gate of the London School of Economics (LSE). The following few paragraphs introduce the points they make most relevant to our topic at hand, as their demands closely mirror the criticisms that business and economic thinkers, educators and policymakers are facing. Their central argument is that current economic trends are leading us to ecological peril, and that poverty and growing inequality cause social problems.

While economics prides itself on being scientific and value-free, and hides behind statistics, mathematical models and graphs, in reality, it acts as an ideology and a belief system that no longer questions its basic assumptions (see e.g., Nelson, 2014). Neoclassical economics teaching is highly mathematised, students are rarely required to apply critical thinking and often leave the higher education system fully indoctrinated.

Much in line with the RRI principles, the theses also state that the underpinning theories of utilitarianism sacrifice the ecological environment and social groups at the less fortunate end of the spectrum completely on the altar of supposedly increasing social welfare without considering the uneven distribution of this welfare. The environment is treated as an external circumstance of the economic system rather than recognising that the economy is an integral part of both the ecological biosphere and the social realm. Markets are not abstract concepts, nor are they 
simply about supply and demand, and the ultimate goal should not be to keep markets free from interventions.

The reformist theses pinned to the gate of LSE also offered solutions regarding how economics teaching can address these problems. In agreement with many scholars (e.g., Capra \& Luisi, 2014) courses should be pluralist in their approaches, offering different perspectives on economic theory. Curricula should be inter- and transdisciplinary in offering sociology, philosophy, environmental sciences, psychology and other disciplines in order to shed light on the complex interrelationships of economic choices. Economics should not be defined as value-free, and its value and moral choices should be made explicit in dialogue with the public. The methodological supremacy of quantitative methods should be rebalanced with qualitative methods.

Similarly to the organisations mentioned above, UNESCO has also been trying to find solutions to introduce sustainability into education (UNESCO, 2014). The Hungarian National Commission for UNESCO, together with Eötvös Lóránd University and the Hungarian Academy of Sciences, held an interactive conference on the topic of 'Sustainability in Higher Education' in November 2018. The report issued (Lányi \& Kajner, 2019) on the findings and recommendations of this panel identified the most urgent tasks: the acknowledgement of the ecological crises, and the responsibility of the higher education system in tackling it; the strengthening of the role of philosophical and ethical reflection in education; engaging students in practical experience to change attitudes; rethinking teacher training and methodologies; and encouraging every department of every discipline to include the issue of sustainability.

Sustainability in economic higher education had its own section within this event, and the participants issued their recommendations in the subsequent report. The recommendations significantly overlap with the suggested actions included in the 33 reformation theses, but are more specific in some points, and relate to the Hungarian context. The following points are summaries and partly direct translations of the original document (Lányi \& Kajner, 2019, pp. 81-83).

1. Economic training must present all economic activity in the context of its human and natural environment. Philosophical, ethical, and cultural anthropological knowledge should become an integral part of economic higher education. Training opportunities must seek to improve the students' ability for critical thinking, discuss the concept of "good life" (Syse \& Mueller, 2014) and the responsibility of humans.

2. Practical, project-based, multidisciplinary teaching methods must replace inefficient frontal education as they are more suitable for encouraging students to take into account environmental, social, and ethical dilemmas of economic activity.

3. Modular "green" courses or subjects are not sufficient. The principles of sustainability must be integrated into the whole spectrum of economic higher education. Offering a select few environmen- tal-based courses does not provide the conditions necessary for transformation or breakthrough, as mainstream education would constantly overwrite the pursuit of sustainability, because its curriculum neglects the considerations of negative environmental and social impacts of economic processes.

4. The institutional environment must support the development of sustainability education. Currently, multidisciplinary education is hampered, as university administrations try to create "clear profiles", and project-based education is hindered as it cannot handle the additional burden that comes with such courses. Suggested means by which university administrations can support the integration of sustainability into the training system are by creating the financial conditions; by developing a faculty career model that focuses on educational innovation; by assisting faculty members to engage in awareness-raising, networking events; publications, translations, and publishing books; and by allowing the harmonisation of curriculum design that focuses on providing students with complex, practically usable knowledge, ways of thinking, and "habits of mind".

5. Faculty members should be trained, and professionally and humanly supported to integrate sustainability into their subjects. Those who teach contrary to the mainstream usually face additional burdens, as they go against the indoctrination of students. There is a need to ensure the continuous update of sustainability knowledge and training methodology and the training of trainers. Many non-economic higher education institutions also deal with sustainability issues. Interdisciplinary dialogue should also be available to get to know them and develop mutual consistency. More workshops, forums, and events that help the exchange of experience between higher education institutions with different profiles should be encouraged.

The recommendations suggested by the various actors at both the national and international level are to be taken seriously, but the devil lies in the details. How can we get these new messages across? How can we deeply transform the ways we teach? What could make students more aware of sustainability problems and more critical of the paradigms that have caused them in the first place? And even if we could manage to get the message across, how can someone practice those principles once they have graduated? To find the answers to these questions, the required shift in higher education must be supported by new methodological approaches, two of which will be discussed in the following chapter.

\section{Teaching sustainability: experiential and transformative learning approaches}

Later in this paper, we introduce two courses that are designed to affect how students frame and problematise sustainability issues. We see these courses as tools and spac- 
es of change. Donella Meadows in her Leverage Points: Places to Intervene in a System (1999) examined how a system can be modified and transformed. She differentiated between "shallow" and "deep" leverage points, which are affect a given system on a different scale (Abson et al., 2017) (Figure 1). tainability issues, rarely reach the deep, foundational levels, where currently prevailing values, worldviews, power structures and rules could be challenged and transformed. It seems that management and economics education is successful in developing anti-social behaviour (Etzioni, 2015) and positive attitudes towards greed (Wang et al.,

Leverage points: Places to intervene in a system

Figure 1.

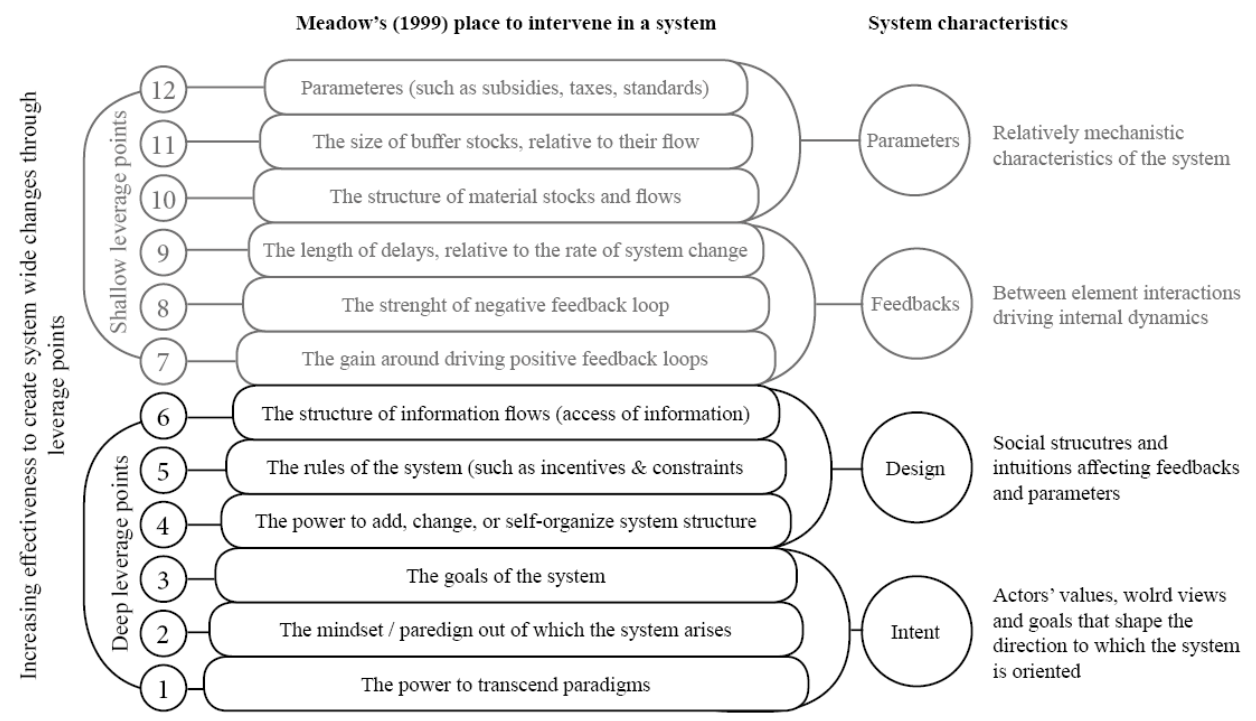

Source: Based on Abson et al. (2017, p. 32)

In our opinion, one reason why all "developed" and many "undeveloped" socio-economic regimes are on unsustainable trajectories (O'Neill et al., 2018) is the shallow level of interventions regarding the respective system. For example, Daly (2007) points out that mere efficiency gains can contribute to greater resource depletion, as overall consumption rises due to the lower prices generated by the increased efficiency. A sustainable trajectory means that basic (deep) concepts of what and why we produce/consume have to be questioned. Accordingly, RRI as a guiding research agenda can be successful if it manages to influence the intentions of the socio-economic (deep) structures. Just like other systems, we argue, higher education and more specifically management programs relating to sus-
2011). Sustainability is one subject, one fragment of the whole, a somewhat materialistic-oriented knowledge-mosaic. Inspired by the 'head, heart and hands' holistic educational approach, we intentionally design our courses and practice teaching accordingly. "Head" stands for the cognitive domain, the action carried out for example through academic study. "Heart" represents the affective domain, the process where values and attitudes are translated into behaviour. "Hands" stand for the psychomotor domain, that is learning through practical skill development and physical labour, such as planting or painting (Sipos et al., 2008, p.74) (Figure 2).

As mentioned above, practical, project-based, multidisciplinary teaching methods may be more suitable for

The 'head, heart and hands' educational approach to sustainability issues

Figure 2.
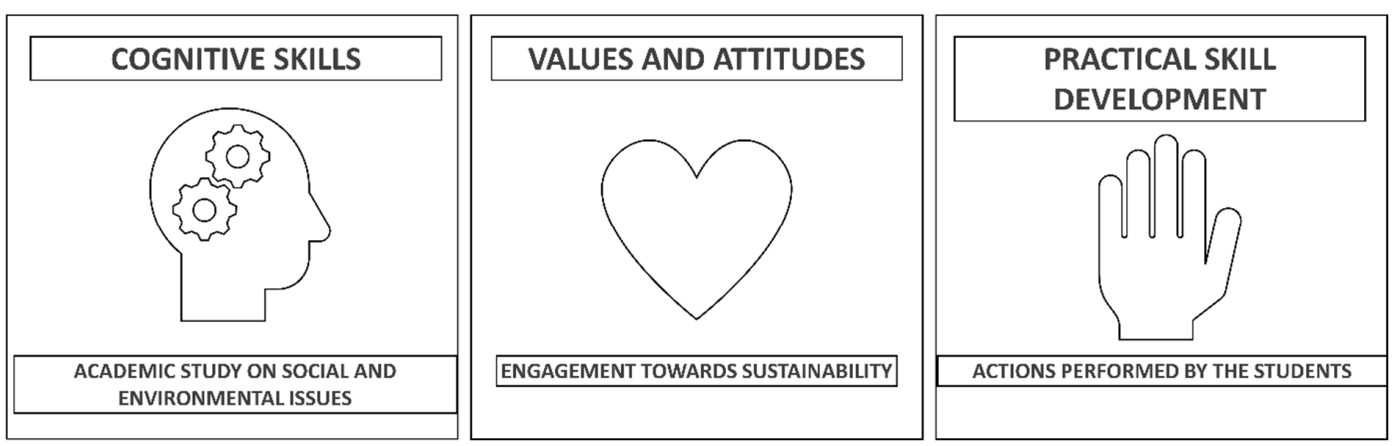
encouraging students to consider the environmental, social, and ethical dilemmas of economic activity. When designing such courses, experiential and transformative learning can serve as guiding frameworks and tools. They have been purposely selected due to their characteristics, which we, as educators, set in line with the RRI vision. A detailed theoretical discussion would exceed space constraints, therefore we only describe those features of the two approaches that we find instructive for our teaching practices.

\section{Experiential learning}

Experiential learning theory emerged through the work of prominent twentieth century scholars, such as John Dewey, Kurt Lewin, Carl Rogers, to name a few, who emphasised experience as the essential element of the learning process (Kolb \& Kolb, 2005). Alice Kolb and David Kolb (2005; p. 208) argue that action, a participative experience, is key in experiential learning, as "it closes the cycle by bringing the inside world of reflection and thought into contact with the outside world of experiences created by action". Experiential learning is more like a philosophy of education based on what Dewey (1938) called a 'theory of experience' (Kolb \& Kolb, 2005, p. 193).

In experiential learning theory, knowledge and meaning are contextualised in actual experiences, where knowledge is created through the experience of action and reflection on that action (Kolb, 1984). The learning process within experiential learning theory is driven by conflict, differences, and disagreement, where participants are "[called] upon to move back and forth between opposing modes of reflection and action and feeling and thinking" (Kolb \& Kolb, 2005, p. 194).

\section{Transformative learning}

As Mezirow (1997) explains, transformative learning is a process intended to develop autonomous thinking, and it does so by affecting change in the individual's frame of reference (personal worldview, system of reality). Transformative learning is achieved when a change occurs to our frame of reference as a result of an event or experience. Where such a change occurs, participants can expect to see a subsequent change in action, and this is what is classified as transformative learning (Mezirow, 2003).

Mezirow (1997) sets the ideal conditions for discourse to take place in the learning space. These conditions are met when participants are:

- provided with the information needed to pursue knowledgeable interactions,

- taking part in the learning process by their own will, free of coercion,

- allowed to take various roles in debates, to change their views and express them,

- encouraged to question 'basic truths',

- open to different perspectives, and

- willing to put effort into listening to other perspectives and work to build common ground (Moore, 2005, pp. 81-82).
One of the most challenging dimensions of Mezirow's transformative learning theory is the role of the educator (Moore, 2005). Within the framework of transformative learning, educators take the role of facilitator and provocateur. It is the educator's responsibility to assist students in their critical reflection when challenging previously unquestioned 'truths', and to help develop the habit and methods of rigorously examining new knowledge. In the transformative learning space, every assumption can be challenged, and participants are required to articulate their arguments and lines of logic (Mezirow, 1997). However, Mezirow (1989) made it clear that an educator should not decide on the outcome of the transformation; if they do, then he considers this indoctrination and not transformation (as cited in Cranton, 1994).

\section{How do experiential and transformative learning approaches compare to each other?}

Both approaches - experiential and transformative learning - disrupt the habits of frontal educational methods. In both methods students are active participants in their learning process, constantly challenged to reflect on their assumptions, articulate their thoughts and feelings. The learning spaces are also required to provide a safe environment in which to encourage discussion and share doubts and feelings.

Both approaches seem to be fit, at least in theory, to provide a framework which allows participants to learn sustainability issues beyond the intellectual level, and also engage emotionally. In our view, participants have to unlearn the doctrine of unlimited economic growth, to be willing and capable of dealing with the emotionally and intellectually demanding facets of sustainability.

In our interpretation such outcomes are not completed or finished in either transformative or experiential learning. Both are processes, and thus can only be practiced, but not achieved. It can be a source of frustration to be involved in a never-ending cycle of questioning oneself, debating, and resolving conflicts. When it comes to the (rather complex) issue of sustainability, students might encounter the destructive quality of their everyday actions, as most of our consumption and production patterns are intertwined with the hostility of modern life. Such recognition might cause emotional distress.

Table 1.

\section{The main features of transformative and experiential learning}

\begin{tabular}{|l|l|}
\hline \multicolumn{1}{|c|}{ Transformative learning } & \multicolumn{1}{c|}{ Experiential learning } \\
\hline Critical reflection & Reflection \\
\hline $\begin{array}{l}\text { Educator's role: facilitator and } \\
\text { provocateur }\end{array}$ & $\begin{array}{l}\text { Educator's role: facilitator, } \\
\text { safe learning environment }\end{array}$ \\
\hline Change in frame of reference & Real-life experience \\
\hline New habits of mind & Degree of freedom \\
\hline $\begin{array}{l}\text { Autonomous thinking, con- } \\
\text { tested beliefs }\end{array}$ & \\
\hline
\end{tabular}

Source: Own compilation 
Table 1 above displays the main characteristics of transformative and experiential learning that we hand-picked when designing the two courses introduced in the next section. The features highlighted in the table are important to us as educators looking for tools to design courses with specific attributes and goals.

\section{Two illustrative cases of teaching practices}

In this section we showcase two courses: Decision Techniques and Degrowth Economy. The common axioms of both courses are the following:

- sustainability is a transdisciplinary issue that requires non-formal learning methods,

- discourse is a prerequisite for real learning and transformation,

- different knowledge holders possess valuable knowledge,

- the teacher acts as a facilitator in the knowledge co-creation process,

- education plays an important role in social transformations,

- engagement in ecological issues is rooted in our own experiences (it is more than intellectual).

Decision Techniques is a BA level course with the overarching objective of focusing on problem forming and solving, and also on the soft skills required to participate in group work. Accordingly, we relied on experiential learning as a guiding framework when designing the course. As educators, we work on creating and maintaining a safe learning environment where students can practice various problem-solving methods. Experience is generated by the course requirements: students working in groups must set a common goal to find an answer or solution to a real-life problem.

Degrowth Economy is an MA level course, which places students in a participatory decision-making process (a Citizens' Jury), where they are challenged to deal with the complexities and ambiguities of the socioeconomic system. As the name of the course implies, we are designing a learning space which is intended to transform the participants' frames of reference regarding the basic premises of economics.

We gathered primary data from the sources below to describe and analyse the courses:

- reflection papers: student individual and group reflection documents written during and after their participation in the courses,

- data from the university's Student Assessment System (SAS) filled out by students optionally at the end of each semester,

- teacher reflection papers written during and after the courses.

We performed a document analysis on this data (Miles et al., 2014). When formulating the current paper's focus and interpreting data, we also relied on our practical experience as educators, what Gibbs (2007) calls 'practical wisdom'. Our practical experience is influenced - among other things - by the weekly discussions among colleagues where we reflect on the events within the courses (what went wrong, what worked well), and by workshops, conferences and papers focusing on certain elements of the teaching practice. Certainly, there are wider institutional contexts which shape our frame of reference, such as Central Eastern European embeddedness, or the local specifics of CUB; and there might be factors of which we are unaware: the 'unknown unknowns'. In the next subsection we introduce the specific elements of each course: Decision Techniques through the lenses of experiential learning, an Degrowth Economy in light of transformative learning.

\section{Experiential learning case - Decision Techniques}

The first illustrative case is a pilot waste treatment problem where students are working together with a civil society organisation (CSO) and focus on waste prevention in the experiential learning course called Decision Techniques. The group of students presented here is from the 2018/19 course. First, the course is described and then the waste management case is introduced.

Decision Techniques is a BA level obligatory course at CUB in business-related degree programs. Scientifically its educational content is based on decision sciences, management and psychology. The experiential learning approach provides the opportunity to integrate a multidisciplinary approach into a comprehensive problem-solving process. The course is an action-oriented semester-long process. Students form groups of six, where they frame problems, and design and realise actions aiming to challenge or tackle their selected problems.

Students meet weekly in 90 minutes classes during the semester, where they design their group actions. The role of the teacher is to facilitate the preparation of the groups for the techniques and give feedback weekly on the ongoing processes. The semester ends with the groups delivering their actions and presenting their experiences to their peers. The performance evaluation is based on individual and group evaluations.

The flipped classroom method is applied during the course to facilitate preparation for the classes and effective group work in the classroom (Bergmann \& Sams, 2012). Students also receive videos and written study materials as part of their individual online preparation. We also use the blended learning approach (Friesen, 2012) whereby students upload their weekly reflections and output and receive feedback from the teacher online before the next class. The learning instructions and materials are all available online. Students can also follow their progress and performance continually throughout the semester using an online interface (Figure 3).

The course is intended to develop decision-making skills, facilitation skills, and problem-solving skills, and offers a choice of decision-assisting techniques. The course allows students to make decisions on their own group's terms, but they are required to reflect on their roles as group members, and they are provided with feedback 


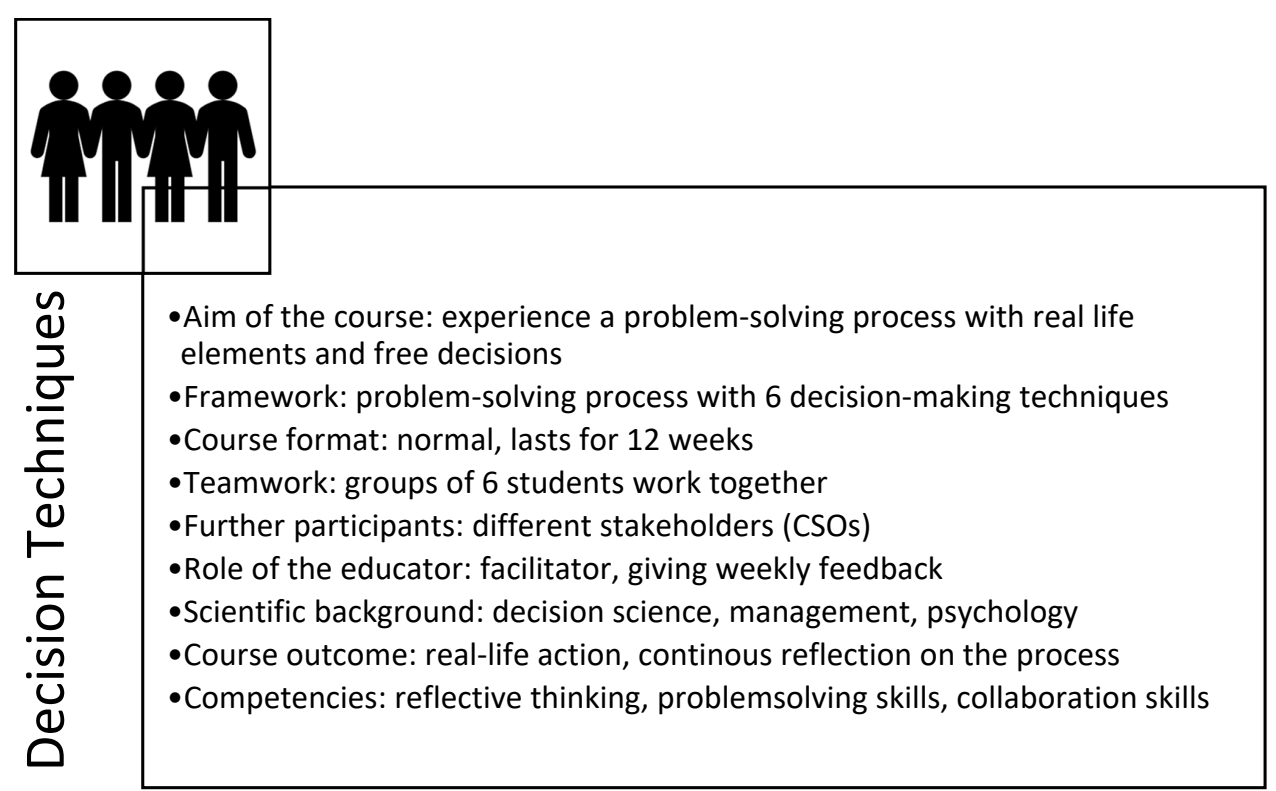

Source: Own compilation

from both their peers and from the educator. Such habits of reflexivity are intended to help deepen student consciousness regarding their role/actions within the group. It also deepens student knowledge of the topic selected for the course during the problem-solving process. The problems are freely selected by the students themselves and they usually involve environmental and social problems e.g., sustainability issues.

Our basic assumption is that engagement cannot emerge without a degree of freedom (Kolb, 1984) that offers the basis for the experiential learning method. During the course, students have responsibility for forming groups based on their fields of interest - they are free to bring topics to the table, and form groups around them. Students are free to decide on the data collection methods assisting their action-design, and the interpretation of the collected data is also within students' competence. What action is taken, and how, is also left to the students to decide and plan. There are however certain elements that remain beyond their influence: the course itself is obligatory, the six decision-assisting techniques are pre-determined, assessment methods for reflecting group and individual performance are given, class attendance is obligatory, actions must be performed and feedback from the teachers must be received.

According to the experiential learning concept, students go through and experience a problem-solving process. In this way they gain real-life experiences and contact real stakeholders involved in the selected problem. To realise the action plan, the group must leave the safe space of the school and measure their ideas and the effect of their actions in real life. The scope of the action depends on the problem chosen by the group at the beginning of the semester and the decisions they took during the problem-solving phase. Every group thus takes different actions in different contexts, and therefore the knowledge they personally build remains unpredictable and diverse.

One of the basic elements of experiential learning is reflection (Kolb, 1984). Reflection is a highly personal and subjective activity, and as such, students may interpret the form of their opinion in many different ways (Humphrey, 2009). A template for a weekly 'reflection diary' is provided, as well as an analysis session for the group work, to help reflection during the course.

According to experiential learning, teacher's role is that of a facilitator of learning (Rogers, 2013). The teacher is responsible for the safe learning environment and gives feedback weekly regarding the reflections and output of the groups.

In the specific case presented here, a group of students - called Clear Corvinus - identified the problem of waste management, explaining that "too much waste is generated at the university". The group formulated the question they were able and willing to solve in the process with the help of decision-making tools: 'How can we increase the amount of social media content that makes Corvinus students aware of waste prevention?' They decided to make a short video about waste prevention alternatives in the university related to student lifestyles. They worked together with a CSO specialised in waste prevention called HUMUSZ. Students consulted with the experts of the CSO and received feedback from them. The video was shared through social media with university students, and also shared by the CSO (13 December 2018 Facebook).

The group concluded after the course:

"We can say that during our project we have also learned a lot about our chosen problem, and we will pay more attention to reducing waste in the future. It was surprising to see how many things we need to think about in order to reduce waste ... but it also surprised us how many 
projects were created on this topic, which led to the conclusion that many students are interested in this problem, and many want to do something about it. Ultimately, we also raised our awareness, as during the lessons we saw how embedded this problem was, how many stakeholders were involved, and we heard useful and shocking information during the interview process (with CSO)."

The course presented here corresponds in theory to the principles of experiential learning based on the freedom of choice and reflection. According to our analysis, student feedback on the course is contradictory. Students who are committed to the course highlighted teamwork, real-life experiences, immersion in the subject, and the pleasure of working together, however, many students were unable to commit to the course. The students identified several reasons for this: frustrating teamwork, meaningless tasks, time-consuming tasks, inappropriate topic selection, non-professional knowledge transfer, and questioning the role of the teacher. These students did not understand the role of 'reflection' and could not engage in their topic either.

In response to feedback, the team of teachers are reflecting weekly and further developing the course (teaching materials, teacher facilitation, tasks, tests etc.) every semester. We assume that some elements of the course do not provide decision-making freedom for students, and we are moving forward to breakdown these barriers.

Some feedback also raise questions that are rooted in the Hungarian higher education system and our operating environment:

- soft skills development is not recognised or valued,

- the role of the teacher is based on power relations, and does not facilitate the development of partnerships between students and teachers,

- the role of the teacher as facilitator is not accepted in our course.

Finally, we assume that - based on our illustrative case - teaching sustainability embedded in an obligatory business school BA course allows the mindset of sustainability to be established in everyday thinking in a learning process. The real-life experiences of knowledge sharing practices and action-oriented cooperation can enhance student engagement and a deeper understanding of sustainability-related issues, and also serves the third mission of the university. However, in our experience, the education system can hinder the achievement of these goals. Discrepancies can arise between the teacher's intentions (curriculum and methodology of the course) and the requirements and constraints set by the university's bureaucratic apparatus, which can lead to frustration for both students and teachers. For example, in our case, we would like to create a learning environment where students are encouraged to take risks, raise questions, take a stance and be willing to change their minds, however, as educators, we are required to give grades that introduce numerical assessment into the student-teacher relationship, which is not exactly a comforting environment that invites students to open up. Also, since the course is obligatory, the experiential learn- ing principle of taking part freely, without coercion, is violated, and therefore student engagement is suppressed.

\section{Transformative learning case - Degrowth Economy}

The second illustrative case built on transformative learning is a Master's level course called Degrowth Economy, built on a participatory decision-making tool called Citizens' Jury. It was first launched in the autumn of 2018/19. The 18-member student group presented here attended this first course at CUB.

Degrowth Economy is an elective course open to all Master's degree programs. Its scientific content is based on ecological economics. Its format is a so-called intensive course' as the course lasts for three intensive days (4x90 minutes per day). Blended learning, online reading materials and instructions are shared before the course and can be used by students at any time during the course. After the three-day intense work, students prepare a reflection paper contemplating the overall process individually and receive individual feedback from teachers in writing on the online platform.

The organisation of the course aligns itself as much with the methodology of the Citizens' Jury as possible. It lasts for three days, and experts from the field of degrowth and ecological economics are invited. The whole framing of the course is established as a Citizens' Jury, including the communication of the teachers (they call the students 'citizens' from the beginning).

In the Citizens' Jury, participants do not need to have extensive knowledge of the matter at hand, as they receive balanced information from experts regarding the pros and cons of the issue discussed. The transdisciplinarity of the issue also comes across better to students, as experts from different fields provide their insights. The experts are invited from various sectors: $\mathrm{CSO}$, academia and business. Students discuss the experts' statements and afterwards deliberate on them with their peers. On the third day of the process, they prepare a recommendation for the decision-maker on the topic. The outcome of the course is a document written by 18 participants based on their consensus.

The course runs in cooperation with the National Council for Sustainable Development in Hungary (NCS$\mathrm{DH}$ ), as the real decision-maker in sustainability issues in Hungary. In this particular course, the Secretary of the Council was invited to ask the students a real-life question at the beginning of the process. The NCSDH is also open to considering the results. Even though they have no obligation to follow the suggestions made by the Citizens' Jury word by word, the advantages of this cooperation are clear for both sides. For the decision-maker it provides a clearer picture of how citizens react to an issue, and the consensual solutions that may arise. This cooperation makes the course more realistic and provides sincerity to the process.

The role of teachers in that process are twofold: one is a so-called 'permanent expert' participating throughout the whole three-day process, but behaving like an expert, 
giving short introductions to topics but intervening only when addressed by the participants. The other teacher is the facilitator, behaving as a non-expert, facilitating the discussions, and conducting the three-day meeting according to a pre-published schedule (Figure 4). tions: after the course they thought or talked about things that were discussed over the three days, they learned things more deeply, experienced real discussions, and felt responsibility for the common output. A few examples of their feedback:

Main characteristics of Degrowth Economy course

Figure 4 .

\begin{tabular}{|l|l|}
\hline & -Aim of the course: learn about the concept of degrowth through discussions, \\
experience active citizenship
\end{tabular}

Source: Own compilation

Citizens' Jury is a decision-making method which is designed to allow stakeholders to formulate well-informed opinions, and suggestions regarding complex situations affecting them (Coote \& Lenaghan, 1997). By default, a small group of 10-18 persons work for 3-4 days, and formulate suggestions addressed to the decision-maker based on various input and consultations with experts. The Citizens' Jury method is built on Habermas' (1984) concept of an ideal speech situation: fairness, competence and transparency are among the important principles in the participatory decision-making processes (Kerkhof \& Wieczorek, 2005; Renn et al., 1995).

A university course has a great deal to do to create a safe and democratic environment in which students can meet the criteria for an ideal speech situation. The number of participants must be low (up to 20 in our case). The power relationship between teacher and student must be equal. Democracy in education can be realised on the basis of the notion that the role of the teacher is that of a facilitator, and the knowledge holders come from different fields: experts, citizens, teachers and students.

Our analysis shows that the circumstances of learning were a great pleasure for students and teachers alike. All the students were engaged in the discourses and gave positive feedback on the course. Not all of the students were immersed in the degrowth concept, but everyone assumed that this way of learning was enjoyable; the topics were interesting and made them think about new concepts. The transformation was also mentioned in the students' reflec-
"The great advantage of the method was that it helped my creativity, and the opinions of others were very inspiring to me."

"I read in advance there would be a CJ, but there is a huge difference between description and living. You can really understand the essence of the method if someone is involved."

"It was very important to me that I did not have to rush with the material like any other subject, but that there was time to think about things and share our thoughts with others."

"In my opinion, the output is much more worthwhile. We discussed, talked, evaluated and came to a common point together, so that really everyone came from around the world, growing up and experiencing things around the country."

In addition to the positive feedback, the students made several criticisms. Most concerned the topic, or the presentation of the invited experts. This also leads to the conclusion that emerged from the debates. Teachers have a huge responsibility for selecting the topics and inviting the experts, as these have a real impact on the experiences.

These results reinforce the way that the Degrowth Economy course illustrates transformative learning. This is based on its main characteristics: built on critical reflection and the role of teachers as facilitators and provocateurs. The methodology of the course is a real-life deliberative process that can induce changes in the frame of reference, new habits of mind, autonomous thinking and the validation of contested beliefs through discourses. 
Students are free to express their reservations, feelings and concerns in this course, and at the same time they need to aim for some form of consensus on the matter. As they deliberate the matter at hand among themselves rather than being given ready-made thoughts, paradigms and solutions by lecturers, reflexive processes are more likely to occur. The suggestions they make at the end of the process is fed into a real decision-making process. In this way the methodology assists critical reflection on both the topic of degrowth and on mainstream economic paradigms. This methodology is intended not just to inform students about the concepts of degrowth but also to experience what active citizenship would mean.

Teaching degrowth or ecological economics in business schools is a challenge, going against all concepts and paradigms that students will have been taught by the time they participate. As a novelty, this course is based on a deliberative methodology, where students have the freedom to make up their minds on what they think about the issue of degrowth.

This learning process is suitable not only for transferring knowledge and changing the frame of reference of participants but is also expected to contribute to real social change. Transformative learning is not about storing knowledge, but about initiating longer-lasting changes in attitudes, mental representations and the connotations created in meaning-making (Ormrod, 2011). At the same time, there can be social learning "side-effects" of participatory decision-making techniques (Kerkhof \& Wieczorek, 2005; Voss et al., 2009). Moreover, it was also important in the design of an ecological economics course to promote active citizenship, which is considered vital in inducing social transformations.

There were some contradictory experiences for teachers, in addition to the enjoyable process. In contrast with the frontal teaching method the topics that were discussed were not always in line with ecological economics or strong sustainability. As is clear in transformative learning, the freedom of expressing feelings and thoughts through discourse leads to unpredictable outcomes (Cranton, 2002). The teacher does not have a direct effect on learners' individual changes in their frame of reference. The autonomous thinking of students and the facilitator role of teachers mean that the conclusions of debates can contrast with the intentions of the teachers or experts or can lead to solutions that are off the desired track. It needs to be accepted that discourse alone cannot ensure that our decisions will support the protection of natural values (Brulle, 2002; Eckersley, 1999). Despite these shortcomings, deliberative democracy and participatory decision-making are considered important tools in advancing sustainability (Arias-Maldonado, 2007).

The real result of the course is happening at a personal level in every student's 'head, heart and hands' and making changes in their habits of mind, however, these changes may not be clearly visible to the teachers themselves.

\section{Discussion and Conclusion}

The two courses provided insights on how the non-formal - experiential and transformative - learning approaches assist our quest (in line with the RRI vision) to change the way sustainability is framed, responsibility is encouraged, and frames of reference are shifted. In many aspects these courses are successes, and in some they are failures. We sum up these experiences in the discussion.

Kolb (1984) states, regarding the experiential learning concept, that to gain genuine knowledge from an experience, the learner must have the following abilities. Firstly, the learner must be willing to be actively involved in the experience. From our cases, it is clear that engagement is a prerequisite of all forms of learning, and educators need to focus on how this engagement can emerge during the course itself. However, a compulsory course - such as Decision Techniques - is seriously hindered in this regard compared to an elective course - such as Degrowth Economy - where students were actively expressing their willingness to become familiar with the topic from the very beginning. This suggests that it might be better for university administrators to try and allow as much freedom of choice for individual curricula for each student as possible. When the freedom of choice is violated - as in the cases of obligatory courses - there is still room to allow students some level of agency over their learning process - but limitations need to be considered. For example, grades must be given, which introduces a whole set of incentives and power relational dynamics among students, and in the learner-teacher relationship; or the fact that a significant number of students claim to prefer frontal knowledge transfer by an approved knowledge-authority rather than participating in tasks designed to polish personal soft skills.

Secondly, the learner must be able to reflect on the experience. This means that educators need to provide space and tools for reflection. However, reflection is a skill in itself that is barely taught in the Hungarian school system and is also a skill that ripens with age (and through practice). Even in these two cases, the difference in the willingness to reflect may be the result of the age and experience gap between Bachelor's and Master's level students. In the case of Decision Techniques, it is contradictory in itself that one of the aims of the course is to develop reflective skills but these skills seem to be a prerequisite for making the most of the course itself.

Lastly, the learner must possess and use analytical skills to conceptualise the experience, and decision making and problem-solving skills in order to use the new ideas gained from the experience. In our experience, student learning and attitudes about class participation often involve the gaining of positive knowledge in a frontal, oneway educational setting, rather than an interest in working on soft skills, where they are required to take agency over their learning process. In many cases learning is thus positive knowledge seeking for them, and they feel lost in a setting when the knowledge must be processed by their own experiences and decisions. 
Much of the feedback indicated that some student expectations of what learning and knowledge are, differ significantly from the paradigms behind these two learning approaches. As an example, some of the students focused on what they can use the techniques learnt in the Decision Techniques course for, and whether that knowledge can be used at all, while others see having gained experience with these techniques as a tool for applying this in a real-life environment. This is not to say that positive knowledge is not necessary to understand the world, but a balance needs to be found between focusing on both. This mismatch in expectations can be a source of frustration for both students and educators, however, if this balance is struck, it can also be uplifting, as it was in the Degrowth Economy course. There can also be a mismatch in the way the "truth" is accepted by different knowledge holders. In Decision Techniques courses it is often a struggle to make students accept that CSO representatives are the holders of significant knowledge, and that an interview with them may shed new light on the matter at hand.

This takes us to the topic of the perceived role of the teacher according to the experiential and transformative learning concepts. Some students believe that the educator does not possess knowledge when they take a facilitator's role, and this is the reason why they "pass the responsibility on to the students". On the other hand, it is also difficult for the educator not to pass on their knowledge, but only provide the facilitation that the students need to come up with answers on their own. This is also where power relations come into the picture. Power relations need to be broken down in order to provide safe space for learning at a student's own pace, but this is difficult when the whole educational structure is founded on different roles. Another challenge of the different role of educators in these approaches is the lack of necessary skills on their part. Completely new skills are necessary when taking up facilitation or provocation compared to when teaching frontally. For example, difficult psychological situations can occur during experiential and transformative courses (e.g., a heated debate or a conflict) that need to be resolved on the spot, otherwise, the complete process can take a bad turn. University teachers do not receive pedagogical education nor psychological preparation for such situations. Students are required to become active agents of their learning processes, and their peers' learning processes, which calls for a range of (mainly soft) skills.

Currently, when using transformative learning approaches to induce change it is hard to accept the fact that these transformations are neither visible nor have immediate effects. We may induce personal changes, but these are not conscious and rational, but often unconscious and unpredictable, and may only happen in the longer run. In experiential learning, the development of various skills is not always recognised by the students by the end of the course.

In this paper, we have focused on changes that happen on the individual level of students, however, for a real sustainability transition, social structures must also change. Changing how we teach and introducing new methods into the educational systems that rely on dialogue, reflectivity and deliberation, may just contribute to such transitions.

\section{References}

Abson, D. J., Fischer, J., Leventon, J., Newig, J., Schomerus, T., Vilsmaier, U., von Wehrden, H., Abernethy, P., Ives, C.D., Jager, N. W. \& Lang, D. J. (2017). Leverage points for sustainability transformation. Ambio, 46(Febr), 3039.

https://doi.org/10.1007/s13280-016-0800-y

Arias-Maldonado, M. (2007). An imaginary solution? The green defence of deliberative democracy. Environmental Values, 16(2), 233-252.

https://doi.org/10.3197/096327107780474573

Bajmócy Z. \& Pataki Gy. (2019). Responsible research and innovation and the challenges of cocreation. In Arno Bammé \& Günter Getzinger (eds.), Yearbook 2018 of the Institute for Advanced Studies on Science, Technology and Society (pp. 1-15). München; Wien: Profil Verlag.

Bergmann, J. \& Sams, A. (2012). Flip Your Classroom: Reach Every Student in Every Class Every Day. Alexandria, VA: International Society for Technology in Education.

Brulle, R. J. (2002). Habermas and Green Political Thought: Two Roads Converging, Environmental Politics, 11(4), 1-20. https://doi.org/10.1080/714000651

Capra, F. \& Luisi, P.L. (2014). The systems view of life. A unifying vision. Cambridge: Cambridge University Press. https://doi.org/10.1017/CBO9780511895555

Coote, A. \& Lenaghan, J. (1997). Citizens' juries: Theory into practice. London: Institute for Public Policy Research.

Cranton, P. (1994). Understanding and promoting transformative learning: A guide for educators and adults. San Francisco: Jossey-Bass.

Cranton, P. (2002). Teaching for Transformation. New Direction for Adults \& Continuous Education, 93, 63-72. https://doi.org/10.1002/ace.50

Daly, H. E. (2007). Frugality first. In Bouckaert, L., Opdebeeck, H. \& Zsolnai, L. (Eds.), Frugality: Rebalancing material and spiritual values in economic life (pp. 207-226). Zürich: Peter Lang Publishing.

Deblonde, M. (2015). Responsible research and innovation: building knowledge arenas for glocal sustainability research. Journal of Responsible Innovation, 2(1), 20-38. https://doi.org/10.1080/23299460.2014.1001235

Eckersley, R. (1999). The discourse ethic and the problem of representing nature. Environmental Politics, 8(2), 24-49. https://doi.org/10.1080/09644019908414460

Etzioni, A. (2015). The Moral Effects of Economic Teaching. Sociological Forum, 30(1), 228-233. https://doi.org/10.1111/socf.12153

Foster, G. \& Stagl, S. (2018). Design, implementation, and evaluation of an inverted (flipped) classroom model economics for sustainable education course. Journal of Cleaner Production, 183, 1323-1336. https://doi.org/10.1016/j.jclepro.2018.02.177

Friesen, N. (2012). Defining blended learning. https://www. normfriesen.info/papers/Defining_Blended_Learning_NF.pdf 
Gibbs, P. (2007). Practical wisdom and the workplace researcher. London Review of Education, 5(3), 223-235. https://doi.org/10.1080/14748460701661278

Habermas, J. (1984). The theory of communicative action: Reason and the rationalisation of society (Vol. 1). Boston: Beacon.

Humphrey, C. (2009). By the light of the Tao. European Journal of Social Work, 12(3), 377-390. https://doi.org/10.1080/13691450902930779

International Call for Pluralism in Economics by the International Student Initiative for Pluralism in Economics (2014). http://www.isipe.net/open-letter

Karner, S., Bajmócy Z., Deblonde M., Balázs B., Pataki Gy., Racovita, M., Snick, A., Thaler A. \& Wicher, M. (2016). RRI concepts, practices, barriers and potential levers. FoTRRIS Deliverable D1.1. http:/fotrris-h2020. eu/wp-content/uploads/2016/01/FoTRRIS-D1.1_ v3_01112016.pdf

Kerkhof, M. Van De \& Wieczorek, A. (2005). Learning and stakeholder participation in transition processes towards sustainability: Methodological considerations. Technological Forecasting and Social Change, 72(6), 733-747. https://doi.org/10.1016/j.techfore.2004.10.002

Kolb, A. \& Kolb, D. (2005). Learning Styles and Learning Spaces: Enhancing Experiential Learning in Higher Education. Academy of Management Learning \& Education. 4(2), 193-212. https://doi.org/10.5465/amle.2005.17268566

Kolb, D.A. (1984). Experiential learning: Experience as the source of learning and development. New York: Prentice Hall.

Lányi, A. \& Kajner, P. (eds.) (2019). A Fenntarthatóság Témaköre a Felsőoktatásban. Budapest: UNESCO Magyar Nemzeti Bizottság.

Meadows, D. (1999). Leverage points: Places to intervene in a system. Lynedoch: The Sustainability Institute.

Mezirow, J. (1989). Transformation theory and social action: A response to Collard and Law. Adult Education Quarterly, 39(3), 169-175. https://doi.org/10.1177/0001848189039003005

Mezirow, J. (1997). Transformative learning: Theory to practice. New Directions for Adult and Continuing Education, 74, 5-12. https://doi.org/10.1002/ace.7401

Mezirow, J. (2003). Transformative learning as discourse. Journal of Transformative Education, 1(1), 58-63. https://doi.org/10.1177/1541344603252172

Miles, M. B., Huberman, A.M. \& Saldana, J. (2014). Qualitative data analysis. Thousand Oaks: SAGE.

Moore, J (2005). Is higher education ready for transformative learning? A question explored in the study of sustainability. Journal of Transformative Education, 3(1), 76-91. https://doi.org/10.1177/1541344604270862

Nelson, R.H. (2014). Economics as religion: From Samuelson to Chicago and beyond. Philadelphia: The Pennsylvania University Press.

O’Neill, D. W., Fanning, A. L., Lamb, W. F. \& Steinberger, J. K. (2018). A good life for all within planetary bound- aries. Nature Sustainability, 1, 88-95.

https://doi.org/10.1038/s41893-018-0021-4

Ormrod, J. E. (2011). Human learning. Boston: Pearson.

Owen, R.; Macnaghten, P. \& Stilgoe, J. (2012). Responsible research and innovation: From science in society to science for society, with society'. Science and Public Policy, 39(6), 751-760.

https://doi.org/10.1093/scipol/scs093

Renn, O., Webler, T. \& Wiedemann P. (eds.) (1995). Fairness and competence in citizen participation: Evaluating models for environmental discourse. Amsterdam: Kluwer Academic Publishers. https://doi.org/10.1007/978-94-011-0131-8

Rethinking Economics and the New Weather Institute (2018). 33 Theses for an Economics Reformation. http://www. newweather.org/wp-content/uploads/2017/12/33-Theses-for-an-Economics-Reformation.pdf

Schomberg, von R. (2013). A vision of responsible research and innovation. In Owen, R., Bessant, J. \& Heintz, M. (eds.). Responsible innovation: Managing the responsible emergence of science and innovation in society (pp. 51-75). Chichester: John Wiley \& Sons. https://doi.org/10.1002/9781118551424.ch3

Sipos, Y., Battisti, B. \& Grimm, K. (2008). Achieving transformative sustainability learning: engaging head, hands and heart. International Journal of Sustainability in Higher Education, 9(1), 68-86. https://doi.org/10.1108/14676370810842193

Steffen, W., Rockström, J., Richardson, K., Lenton, T. M., Folke, C., Liverman, D., Summerhayes, C. P., Barnosky, A. D., Cornell, S. E., Crucifix, M., Donges, J. F., Fetzer, I., Lade, S. J., Scheffer, M., Winkelmann, R. \& Schellnhuber, H. J. (2018). Trajectories of the earth system in the Anthropocene. Proceedings of the National Academy of Sciences, 115(33), 8252-8259.

https://doi.org/10.1073/pnas.1810141115

Stilgoe, J., Owen, R. \& Macnaghten, P. (2013). Developing a framework for responsible innovation, Research Policy, 42(9), 1568-1580.

https://doi.org/10.1016/j.respol.2013.05.008

Strange, H. \& Gibson, H. (2017). An investigation of experiential and transformative learning in study abroad programs. The Interdisciplinary Journal of Study Abroad, 29(1), 85-100. https://eric.ed.gov $/$ ?id=EJ1141587

Syse, K. L. \& Mueller, M. L. (eds.) (2014). Sustainable Consumption and the Good Life. London: Routledge.

UNESCO (2014). Shaping the future we want: UN Decade of Education for Sustainable Development; final report. Geneva: UNESCO. https://unesdoc.unesco.org/ ark:/48223/pf0000230171

Voss, J-P., Smith, A., \& Grin, J. (2009). Designing longterm policy: rethinking transition management. Policy Sciences, 42(4), 275-302. https://doi.org/10.1007/s11077-009-9103-5

Wang, L., Malhorta, D., \& Murnighan, J. K. (2011). Economics education and greed. Academy of Management Learning \& Education, 10(4), 643-660. https://doi.org/10.5465/amle.2009.0185 